\title{
Carbon-bearing Wastes as the Binders for Coal Briquette Production
}

\author{
Ihor Petrovich Zasukha \\ Department of Project Management, Kyiv National University of Construction and Architecture, Kyiv, Ukraine
}

\section{Email address:}

igor.zasuha31@gmail.com

\section{To cite this article:}

Ihor Petrovich Zasukha. Carbon-bearing Wastes as the Binders for Coal Briquette Production. Science Research. Vol. 9, No. 1, 2021 , pp. 1-5. doi: 10.11648/j.sr.20210901.11

Received: December 7, 2020; Accepted: December 24, 2020; Published: January 4, 2021

\begin{abstract}
The search of optimal compositions for different kinds of coal (lignite and hard coals) with the slam of lean coal for briquettes production was done. Some cheap and non-toxic binders for increasing mechanic stability and water resistance of coal-slam briquettes were experienced. Tree best kinds of binders from coke-chemical industry wastes for improving the properties of coal briquettes were chosen. The main technological parameters of coal briquetting without a binder additive humidity, size of the pressed coal (dried), pressing pressure, drying temperature and pressing duration are in a certain relationship. To obtain a given briquette strength when changing one of the parameters, it is necessary to change another or several parameters. The dependence of the mechanical strength of briquettes on each individual parameter is often extreme. The value of the parameter at which the maximum strength of the briquettes is obtained is taken as optimal. For coals with good briquetting properties, this extreme dependence of the mechanical strength on individual briquetting parameters is more pronounced, especially for the bending and compressive strength of briquettes. Therefore, in the production of briquettes, an important element in the composition of the coal composition is the binder. The article discusses the search for a binder for the production of fuel briquettes using various grades of coals based on local raw materials.
\end{abstract}

Keywords: Coal, Waste, Binders, Briquette, Water Absorption, Mechanical Stability

\section{Introduction}

Despite many years of successful experience and real achievements, the development of briquette production sector was almost suspended during the last years. Production volume at the briquette factories was decreased to minimum as a result of instability in factory operation caused by raw material deficit, absence of high-quality binders of national production and modern equipment for batching and furnace batch mixing. One of the possible ways to stabilize and expand fuel briquette production is briquette production from different types of carbon-bearing raw material, mainly of the lowest grades, with use of low-cost, readily available and relatively non-toxic binders.

Briquetting is one of reasonable ways to use low-grade brown coals. The issues of briquetting of brown coal and some types of black coals were not studied in details at the appropriate time [1,2]. Brown coal briquettes are highly demanded by the household consumers and municipal utilities due to the low ignition temperature, high reactivity, burning with high flame, absence of adhesiveness and high furnace efficiency factor in process of their burning. Main shortcomings of brown coal briquettes are their low water resistance and insufficient mechanical resistance to abrasion which results in increased dust ductionformation during briquette transportation. Over $40 \%$ of brown coal briquettes turns into the coal dust during storage. Black coal briquettes are featured by the higher combustion heat, low output of volatile substances and low ash content, provided that black coal chips were cleaned, and, at the same time, by low reactivity and insufficient furnace efficiency factor in process of their burning. Integration in briquettes of positive features of brown and black coals, provided that efficient method of combined briquetting is available, allows to develop the improved fuel type.

If coal mining and flotation wastes are used for briquetting, at the same time some environmental issues could be resolved, in particular, processing of carbon-bearing slime which is dramatically accumulated now at the slime dumps.

Briquetting of gas, brown and hard coal mix was 
investigated in the research paper [3]. Bitumen was used as a binder. The results of trials demonstrated that when the content of humite and liptobiolith coals in briquette is increased up to $40 \%$, the briquette strength index and resistance to milling are slightly decreased, and further on these indexes drastically go down. The studies [4] evidenced that heavy coal-tar products, the wastes of coke-chemical industry, are of the certain interest for briquetting of different fine dispersed ores. The possibility to use heavy coal-tar products as a binder for briquetting of coal charge is already known, but not implemented in industry yet [5]. Comparison of the certain materials of coke-chemical and other origin as the binders for briquette production from hard coal chips demonstrated [5] that gas tar and heavy coal-tar products are significantly more efficient than such well-known binders as liquid glass, the wastes of wood processing industry and cement. Acid tar is included in formulations of binders for road construction $[6,7]$, in line with heavy tar, which is a copolymerized and oxidized mix of stillage residues, acid tars and gas tar [8]. The other binders, which are promising for solid briquette production, may also be offered.

The technological scheme of briquetting of coal fines with binders differs significantly from the technological scheme of briquetting brown coals and depends on the type of binder used [9]. Briquetting factories receive screenings of anthracite or lean coal of the class 0-6 mm. Briquetting is carried out with an additive of coal tar pitch or petroleum bitumen [10].

Briquetting with coal tar pitch. Coal screenings arriving at the factory are unloaded into receiving pits, and then dried to a moisture content of 3\% in gas drum dryers. Granular coal tar pitch from warehouse enters the crushing department and is crushed to $1 \mathrm{~mm}$. Dried coal and crushed pitch are fed to the bunker of the dosing department. With the help of disc feeders, coal and pitch are dosed in the required ratio and mixed in a screw conveyor. From the mixing conveyor the charge enters the malaxers of the pressing units, in which it is steamed and heated to $90-100^{\circ} \mathrm{C}$. After cooling in the screw 8 to $80^{\circ} \mathrm{C}$, the charge enters the press rolls and briquettes. After cooling to $40^{\circ} \mathrm{C}$, briquettes are loaded into railway cars [11]. Briquetting with oil bitumen. Coal fines entering the factory from the receiving pits is fed to the drying department of the factory, where it is dried to a moisture content of $2-3 \%$ in the tubes of the dryers. The dried material is fed into the bunker of the pressing unit, from where it is sent by a vibrating batcher to a twin-shaft paddle mixer, into which liquid heated oil bitumen enters. Then the charge enters the malaxer, where it is heated to a temperature of $80-90^{\circ} \mathrm{C}$ and after cooling in a twin-shaft cooler to a temperature of $60-65^{\circ} \mathrm{C}$ briquetted on a roller press. Briquettes after cooling on belt conveyors to $40-45^{\circ} \mathrm{C}$ are loaded into wagons [12]. Used as a binder, petroleum bitumen enters the briquette factory in bitumen bunkers-wagons and is unloaded into a bitumen storage, from where, in a heated state, it is fed into a tube furnace, where it is heated to a temperature of $180(200){ }^{\circ} \mathrm{C}$ and through an intermediate tank is sent for mixing with coal [13]. Bitumen can be produced at the briquette factory itself. In this case, liquid sludge or cracking residues entering the factory in tanks are discharged into a storage facility, from which they are pumped into a tubular furnace and then heated to a temperature of $200-220^{\circ} \mathrm{C}$ are fed into a continuous oxidizing reactor. In the reactor, the heated raw material is oxidized by the air passed through it and sent for mixing with coal [14].

The physicochemical parameters of the briquetting process with binders depend on the briquetting method, the properties of the feedstock, binders used, the conditions for compaction of briquettes, as well as on the rate of polymerization of binders and the formation of various cementing substances in the structure of briquettes, plasticizing additives, and the like.

In the practice of briquetting, liquid and solid binders are used: lignosulfonates, sulfite meadows, water glass, coal tar, bitumen, lime, various combined binders - a mixture of coal tar and tar, limestone, water glass, acid tar (waste of coke production), polymers, coal tar pitch, oil bitumen, etc.

Research on raw material briquetting is carried out in order to study the effectiveness of binding additives, develop technology and modes for increasing and strengthening the strength of the briquetted material. The obtained finished briquettes are examined for mechanical strength, thermal resistance, and water resistance [15].

\section{Research Findings}

The objective of our research paper is to formulate the binder based on carbon-bearing wastes of different origin for production of weather-resistant and mechanically strong briquettes from the mix of low-grade brown coal (BC), black coal of gas grade $(\mathrm{G})$, fat grade $(\mathrm{F})$ and coking grade $(\mathrm{C})$, and carbon-bearing waste - the slime of lean coal $(\mathrm{Sl})$, and to select the best furnace charge compositions.

Standard test methods for initial raw material and furnace charge (technical analysis), the method of furnace charge pressing in presses of different capacity, water absorption test method, and compression strength test method were used.

Specifications of coal and slime used in briquette production are given in the table 1. Brown coal was taken from Konstantinovskyi open-pit mine (Aleksandria town), black coal of gas grade - at Kurakhovskaia central concentration plant, black coal of coking and fat grades - at Proletarskaia central concentration plant, lean coal slime - at Kurakhovskaia central concentration plant.

Table 1. Technical Analysis of Coal and Slime Samples Examined.

\begin{tabular}{|c|c|c|c|c|c|c|}
\hline Coal grade & Sample code & $W^{\mathrm{a}, \%}$ & $A^{d}, \%$ & $V^{\text {daf }}, \%$ & $S_{t}^{d}, \%$ & $\mathbf{Q}_{\mathrm{b}, \mathrm{MJ} / \mathrm{kg}(\mathrm{kcal} / \mathrm{kg})}$ \\
\hline $\mathrm{BC}$ & 1 & 12.37 & 22.72 & 67.44 & 2.68 & $17.87(4271)$ \\
\hline G & 2 & 5,99 & 5,15 & 43,60 & & $31,83(7607)$ \\
\hline $\mathrm{F}$ & 3 & 1,64 & 13,54 & 32.29 & & $29,79(7120)$ \\
\hline $\mathrm{C}$ & 4 & 2.15 & 14.37 & 24.18 & & $31,22(7461)$ \\
\hline Sl & 6 & 19.93 & 28.51 & 17.90 & & $18,5(4424)$ \\
\hline
\end{tabular}


The following mixes with decrease of brown coal percentage, increase of slime percentage and constant quantity of added coal of different grades (gas G, coking C and Fat F) were studied:

$60 \% \mathrm{BC}+20 \% \mathrm{Sl}+20 \% \mathrm{coal}$

$50 \% \mathrm{BC}+30 \% \mathrm{Sl}+20 \%$ coal

$40 \% \mathrm{BC}+40 \% \mathrm{Sl}+20 \% \mathrm{coal}$

$30 \% \mathrm{BC}+50 \% \mathrm{Sl}+20 \%$ coal.

12 three-component mixes with different percentage of brown coal, slime and coal were prepared: brown coal, lean coal slime $\mathrm{L}$ and coal of $\mathrm{F}$ grade (mixes Nos. 1-4), coal of C grade (mixes Nos. 5-8), coal of F grade (mixes Nos. 9-12).

Samples were briquetted at furnace charge temperature approximately $50^{\circ} \mathrm{C}$ in press with special moulds, with inner cylinder diameter $25 \mathrm{~mm}$, under the pressure $150 \mathrm{~atm}$ or $42-45$ $\mathrm{kg} / \mathrm{cm}^{2}$, and in press HL-100 under the pressure 1000-1100 $\mathrm{kg} / \mathrm{cm}^{2}$. Maximum water absorption tests were conducted according to GOST 21290-75, compression strength tests according to GOST 21289-75. 8 binder types were tested: the wastes of coke-chemical industry (heavy coal-tar products Cct acid tar At, polymers $\mathrm{Cp}$ and tar $\mathrm{Ct}$ ), the wastes of oil refining industry (petrolatum Clat), the wastes of pulp and paper industry (lignosulfonate in liquid and powder Clsf), oil slime (oily washing wastes Coww).

The results of water absorption by binder-free briquettes made of three-component mix with distribution by composition are shown in the table 2 .

Table 2. Water absorption by test briquettes made of three-component mix of brown coal, slime of L grade and black coal of $G, F$ and $C$ grades.

\begin{tabular}{lll}
\hline \multirow{2}{*}{ Mix No. } & Material & Water absorption without binder W, $\pm \mathbf{0 , 5}$ : \\
\cline { 2 - 3 } & BC & $\mathbf{2 2 , 1}$ \\
\hline 1 & $60 \% \mathrm{BC}+20 \% \mathrm{Sl}+20 \% \mathrm{G}$ & 15,4 \\
2 & $50 \% \mathrm{BC}+30 \% \mathrm{~S}+20 \% \mathrm{G}$ & 16,2 \\
3 & $40 \% \mathrm{BC}+40 \% \mathrm{Sl}+20 \% \mathrm{G}$ & 18,2 \\
4 & $30 \% \mathrm{BC}+50 \% \mathrm{Sl}+20 \% \mathrm{G}$ & 17,3 \\
5 & $60 \% \mathrm{BC}+20 \% \mathrm{Sl}+20 \% \mathrm{C}$ & 19,8 \\
6 & $50 \% \mathrm{BC}+30 \% \mathrm{Sl}+20 \% \mathrm{C}$ & 19,2 \\
7 & $40 \% \mathrm{BC}+40 \% \mathrm{Sl}+20 \% \mathrm{C}$ & 20,0 \\
8 & $30 \% \mathrm{BC}+50 \% \mathrm{Sl}+20 \% \mathrm{C}$ & 20,1 \\
9 & $60 \% \mathrm{BC}+20 \% \mathrm{Sl}+20 \% \mathrm{~F}$ & 17,5 \\
10 & $50 \% \mathrm{BC}+30 \% \mathrm{Sl}+20 \% \mathrm{~F}$ & 17,2 \\
11 & $40 \% \mathrm{BC}+40 \% \mathrm{Sl}+20 \% \mathrm{~F}$ & 18,4 \\
12 & $30 \% \mathrm{BC}+50 \% \mathrm{Sl}+20 \% \mathrm{~F}$ & 20,2 \\
& $\mathrm{Slim} \mathrm{Sl}$ & Over 32 \\
\hline
\end{tabular}

As we see, the briquettes made of mix No. 1, formulation $60 \%$ $\mathrm{BC}+20 \% \mathrm{Sl}+20 \% \mathrm{G}(15,4 \%)$ are featured by the lowest water absorption, the trend of briquette water absorption increase in line with increase of slime Sl content in the mix is observed. In order to facilitate analysis of binder effect, the briquettes made of mix No. 3 with ratio in percent $40 \% \mathrm{BC}+$ $40 \% \mathrm{Sl}+20 \% \mathrm{G}$, which are the briquettes with maximum water absorption $(18,2 \%)$ were selected to test the effect of binders.

Water absorption of binder-free briquettes made of three-component mix of brown coal, slime $\mathrm{L}$ and coal of $\mathrm{C}$ grade is almost not dependent on briquette composition, it amounts to $20,0-20,1 \%$. The briquettes made of mix No. 7 with ratio in percent $40 \% \mathrm{BC}+40 \% \mathrm{Sl}+20 \% \mathrm{C}$ (water absorption 20,0\%) were selected to test the effect of binders.
Water absorption of briquettes made of three-component mix of brown coal, lean coal slime $\mathrm{Sl}$ and coal of $\mathrm{F}$ grade depends on briquette content. Water absorption increases in line with increase of slime content and decrease of brown coal content in the mix. The mixes No. 5 , formulation $60 \%$ $\mathrm{BC}+20 \% \mathrm{Sl}+20 \% \mathrm{~F}(17,5 \%)$ and No. 6, formulation $50 \%$ $\mathrm{BC}+30 \% \mathrm{~S} 1+20 \% \mathrm{~F}(17,2 \%)$ are featured by the lowest water absorption, and the mix No. 8, formulation $30 \% \mathrm{BC}+$ $50 \% \mathrm{Sl}+20 \% \mathrm{~F}(20,2 \%)$ have the highest water absorption. Briquettes made of the mix No. 11 with the same percentage as for the previous coals, i.e. $40 \% \mathrm{BC}+40 \% \mathrm{Sl}+20 \% \mathrm{~F}$ (water absorption 18,4\%) were selected to test the effect of binders. Results of water absorption by briquettes made of three-component mixes with addition of different binders are shown in the Table 3.

Table 3. Water absorption by test briquettes made of three-component mix, formulation $40 \%$ BC $+40 \% S l+20 \%$ of black coal of $G$, C and $F$ grades, with binders.

\begin{tabular}{|c|c|c|c|}
\hline \multirow{2}{*}{$\begin{array}{l}\text { Sample } \\
\text { Coal, grade }\end{array}$} & \multicolumn{3}{|c|}{ Water absorption W, \% } \\
\hline & $\mathbf{G}$ & $\mathbf{C}$ & $\mathbf{F}$ \\
\hline Initial mix $40 \% \mathrm{BC}+40 \% \mathrm{Sl}+20 \%$ coal & 18,2 & 20,0 & 18,4 \\
\hline $90 \%$ of $\operatorname{mix}+10 \% \mathrm{Cct}$ & 14,3 & 7,5 & 14,0 \\
\hline $90 \%$ of mix $+10 \% \mathrm{Cp}$ & 12,4 & 4,8 & 15,1 \\
\hline $90 \%$ of mix $+10 \% \mathrm{Cp}$ & 8,7 & 9,4 & 5,7 \\
\hline $90 \%$ of $\operatorname{mix}+10 \% \mathrm{Ct}$ & 4,7 & 7,4 & 3,9 \\
\hline $90 \%$ of mix $+10 \%$ Clat & 4,3 & 2,7 & 5,1 \\
\hline $90 \%$ of mix $+10 \%$ Coww & - & 7,0 & 5,3 \\
\hline $80 \%$ of $\operatorname{mix}+20 \% \mathrm{Ct}$ & 3,8 & - & - \\
\hline
\end{tabular}


As we see, the briquettes with formulation $90 \%$ of $\operatorname{mix}+10 \%$ petrolatum Clat binder (4,3\%) and briquettes with tar $\mathrm{Ct}(4,7 \%)$ have the lowest water absorption among all briquettes made of the mix No. 3, formulation $40 \% \mathrm{BC}+40 \% \mathrm{Sl}+20 \% \mathrm{G}$. It was established that addition of $20 \%$ of $\mathrm{Ct}$ binder to $80 \%$ of mix by weight results in even higher $(4,8$-fold) decrease of water absorption (up to 3,8\%). In addition, almost 2-fold decrease of water absorption of briquettes made of the mix No. 3 is observed when copolymer $\mathrm{Cp}$ binder is added. Water absorption in this case is $8,7 \%$, and water absorption of briquettes made of initial mix No. 3 is $18,2 \%$.

Research results demonstrate that all briquettes with addition of coal of $\mathrm{C}$ grade and binder have the lower water absorption than initial briquettes $(20,0 \%)$. The following binders gave the best results: petrolatum Clat $(2,7 \%)$, acid tar At $(4,8 \%)$, tar Ct $(7,4 \%)$, polymers $\mathrm{Cp}(9,4 \%)$. The briquettes with addition of petrolatum Clat binder appeared to be the most high-quality from the point of view of water absorption (7-fold decrease to compare with binder-free briquettes).

In case of the coal of $\mathrm{F}$ grade the acid tar At and heavy coal-tar products Cct almost do not decrease briquette water absorption, and polymers Cp, oil slime Coww, petrolatum Clat and tar $\mathrm{Ct}$ significantly decrease water absorption. The following binders gave the best results: tar $\mathrm{Ct}(3,9 \%)$, petrolatum Clat $(5,1 \%)$, oily washing wastes Coww $(5,3 \%)$, polymers $\mathrm{Cp}(5,7 \%)$. The briquettes with addition of binder tar $\mathrm{Ct}$ appeared to be the most high-quality from the point of view of water absorption (4,7-fold decrease to compare with binder-free briquettes).

Therefore, such binders as petrolatum, tar and polymers, the wastes of oil and coal chemical industry, are recommended for briquettes containing the coal of $\mathrm{G}$ grade as per the parameter of briquette water absorption.

Petrolatum, tar, polymers, and acid tar after sufficient heating and mixing demonstrated the good results as binders in the mixes containing the coking coal.

Tar, petrolatum and polymers are suitable binders for the briquettes made with addition of coal of $F$ grade.

It should be noted that lignosulfonate, liquid or powder, according to the parameter of water absorption in three-component systems, is not suitable as a binder because of increase of water absorption; the briquettes made with this binder immediately decompose in water.

Mechanical compression strength tests of coal slime briquettes were performed. It appeared that compression strength of the briquettes of different composition with addition of gas coal ranges within $70,9-98,5 \mathrm{~kg} / \mathrm{cm}^{2}$. Briquettes made on the mix No. 1 , formulation $60 \% \mathrm{BC}+20 \% \mathrm{Sl}+20 \% \mathrm{G}$, are featured by the highest compressive strength $\left(124,0 \mathrm{~kg} / \mathrm{cm}^{2}\right)$, and briquettes made of the mix No. 4 , formulation $30 \% \mathrm{BC}+50 \% \mathrm{Sl}+20 \% \mathrm{G}$, are featured by the lowest compressive strength $\left(60,4 \mathrm{~kg} / \mathrm{cm}^{2}\right)$ because of increase of slime Sl content in the mix.

Compression strength of briquettes made of different mixes with addition of coal of $\mathrm{C}$ grade ranges within $65,2-93,2$ $\mathrm{kg} / \mathrm{cm}^{2}$. Briquettes made of the mix No. 6, formulation $50 \%$ $\mathrm{BC}+30 \% \mathrm{Sl}+20 \% \mathrm{C}$, are featured by the highest compressive strength $\left(93,2 \mathrm{~kg} / \mathrm{cm}^{2}\right)$, and briquettes made of the mix No. 8, formulation $30 \% \mathrm{BC}+50 \% \mathrm{Sl}+20 \% \mathrm{C}$, are featured by the lowest compressive strength $\left(65,2 \mathrm{~kg} / \mathrm{cm}^{2}\right)$.

Compression strength of briquettes made of different mixes with addition of coal of $F$ grade ranges within 53,2-104,4 $\mathrm{kg} / \mathrm{cm}^{2}$. Briquettes made of the mix No. 10, formulation $50 \%$ $\mathrm{BC}+30 \% \mathrm{Sl}+20 \% \mathrm{~F}$, are featured by the highest compressive strength $\left(104,4 \mathrm{~kg} / \mathrm{cm}^{2}\right)$, and briquettes made of the mix No. 11 , formulation $40 \% \mathrm{BC}+40 \% \mathrm{Sl}+20 \% \mathrm{~F}$, are featured by the lowest compression strength $\left(53,2 \mathrm{~kg} / \mathrm{cm}^{2}\right)$.

Compression strength of briquettes made of three-component mix of brown coal, lean coal slime, black coals of G, C, F grades and binders is shown in the Table 4 .

Table 4. Compression strength of briquettes made of three-component mix of brown coal, lean coal slime, black coals of $G$, $C$, $F$ grades and binders.

\begin{tabular}{|c|c|c|c|}
\hline \multirow{2}{*}{$\begin{array}{l}\text { Sample } \\
\text { Coal, grade }\end{array}$} & \multicolumn{3}{|c|}{ Compression strength, $\mathrm{kg} / \mathrm{cm}^{2}$} \\
\hline & G & $\mathbf{C}$ & $\mathbf{F}$ \\
\hline Initial mix $40 \% \mathrm{BC}+40 \% \mathrm{Sl}+20 \%$ coal & 78,2 & 81,2 & 53,2 \\
\hline $90 \%$ of $\operatorname{mix}+10 \% \mathrm{Cp}$ & 230,8 & 224,4 & 224,0 \\
\hline $90 \%$ of $\operatorname{mix}+10 \%$ At & 140,0 & 136,8 & 126,0 \\
\hline $90 \%$ of mix $+10 \%$ Cct & 80,4 & 73,6 & 92,4 \\
\hline $90 \%$ of mix $+10 \%$ Clat & 44,8 & 48,4 & 32,0 \\
\hline $90 \%$ of mix $+10 \%$ Coww & 27,2 & 25,6 & 26,0 \\
\hline
\end{tabular}

Results of the trials demonstrate that compression strength of briquettes made with binders is within the waste range $\left(25,6,-385,6 \mathrm{~kg} / \mathrm{cm}^{2}\right)$, and compression strength of binder-free briquettes made according to the formulation $40 \% \mathrm{BC}+40 \%$ $\mathrm{Sl}+20 \%$ coal is $53,2-81,2 \mathrm{~kg} / \mathrm{cm}^{2}$. It is clearly seen in Table 4 that such binders as tar $\mathrm{Ct}$, polymers $\mathrm{Cp}$ and acid tar At increase significantly the briquette compression strength, and the other binders may even decrease this parameter.

From all briquettes made of the mix No. $3(40 \%$ BC $+40 \%$
$\mathrm{Sl}+20 \% \mathrm{G})$ the highest compression strength have the briquettes with $\mathrm{Ct}$ binder $\left(272,4 \mathrm{~kg} / \mathrm{cm}^{2}\right), \mathrm{Cp}$ binder $(230,8$ $\left.\mathrm{kg} / \mathrm{cm}^{2}\right)$ and At binder $\left(140,0 \mathrm{~kg} / \mathrm{cm}^{2}\right)$.

Therefore, suitable binders for the mix No. $3(40 \% \mathrm{Bc}+$ $40 \% \mathrm{Sl}+20 \% \mathrm{G})$ according to the parameter of water absorption are such carbon-bearing wastes as petrolatum $\mathrm{Cp}$, tar $\mathrm{Ct}$ and polymers, and according to the parameter of mechanical strength - such wastes as tar $\mathrm{Ct}$, polymers $\mathrm{Cp}$ and acid tar At. 
Compression strength of briquettes made of the mix No. 7, formulation $40 \% \mathrm{BC}+40 \% \mathrm{Sl}+20 \% \mathrm{C}$, and addition of above-mentioned binders ranges within $362,0-25,6 \mathrm{~kg} / \mathrm{cm}^{2}$, and their compression strength without binders is $81,2 \mathrm{~kg} / \mathrm{cm}^{2}$. It is evident (similarly to the previous case, for addition of coal of $\mathrm{F}$ grade) that the binders $\mathrm{Ct}, \mathrm{Cp}$ and $\mathrm{CK}$ increase significantly the briquette compression strength. Briquettes with tar Ct binder $\left(362,0 \mathrm{~kg} / \mathrm{cm}^{2}\right)$, polymers $\mathrm{Cp}$ binder $(222,4$ $\left.\mathrm{kg} / \mathrm{cm}^{2}\right)$ and acid tar At binder $\left(136,8 \mathrm{~kg} / \mathrm{cm}^{2}\right)$ are featured by the highest compression strength. To compare with binder-free briquettes, 4,4-fold increase of compression strength of briquettes made of the mix No. 7, formulation $40 \%$ $\mathrm{BC}+40 \% \mathrm{Sl}+20 \% \mathrm{C}$, is observed after addition of $10 \% \mathrm{Ct}$ tar binder, 2,7-fold increase is observed after addition of polymer $\mathrm{Cp}$ binder, and 1,6-fold increase is observed after addition of acid tar At binder. Therefore, suitable binders for the mix $40 \% \mathrm{BC}+40 \% \mathrm{Sl}+20 \% \mathrm{C}$ according to the parameter of water absorption are petrolatum, tar, polymers, and acid tar after sufficient heating and mixing, according to the parameter of mechanical strength - the tar, polymers and acid tar.

The similar tests were performed with briquettes made of the mix No. 11, formulation $40 \% \mathrm{BC}+40 \% \mathrm{Sl}+20 \% \mathrm{~F}$ with addition of above-mentioned binders. Compression strength of briquettes with binder ranges within $385,6-26,0 \mathrm{~kg} / \mathrm{cm}^{2}$, and compression strength of binder-free briquettes made of the mix No. 11 is $53,2 \mathrm{~kg} / \mathrm{cm}^{2}$. Similarly to the previous cases, for coal of $\mathrm{G}$ and $\mathrm{C}$ grades the binders $\mathrm{Ct}, \mathrm{Cp}$ and $\mathrm{At}$ significantly increase compressive strength. The following briquettes are featured by the highest compressive strength: with tar $\mathrm{Ct}$ binder $\left(385,6 \mathrm{~kg} / \mathrm{cm}^{2}\right)$, polymer $\mathrm{Cp}$ binder $(224,0$ $\left.\mathrm{kg} / \mathrm{cm}^{2}\right)$, acid tar At binder $\left(126,0 \mathrm{~kg} / \mathrm{cm}^{2}\right)$ and heavy coal-tar products Cct binder $\left(92,4 \mathrm{~kg} / \mathrm{cm}^{2}\right)$.

\section{Conclusion}

In general, some coke chemical wastes which have the necessary qualities, namely, tar, polymers and acid tar, may be considered the most promising binders for high-quality fuel briquette production. Acid tar deposits are really significant and require immediate disposal. In line with that behavior of sulfur compounds in process of briquette use and many other issues of theory and practice of high-quality briquette production from non-traditional raw materials with use of different carbon-bearing wastes need to be examined.

\section{References}

[1] Elishevich A. T. Briquetting of Mineral Resources - Kyiv: Odessa-Lybid, 1990. -295 pgs.

[2] Sviatets I. E. Brown Coal Technologic Applications. M.: Nedra, 1985. - 207 pgs.

[3] Blahov I. S., Sviatets I. E., Ahroskin A. A. Production of Household Fuel Briquettes and Coking Briquettes from the Mix of Brown and Black Coals // Solid fuel chemistry. - 1976. - No. 4. - Pgs. 12-19.

[4] Yehorov V. M., Malyi E. I. Heavy Black Coal-Tar Products as the Binders and Reducers in Production of Carbon-Ore Briquettes // Carbon Chemical Journal. - 2003. - No. 1-2. - Pgs. 47-48.

[5] Yehorov V. M. Future and Challenges of Coking Technology // Modern Problems of Metallurgy: Scientific papers of NMetAU. - Dnepropetrovsk: System Technologies, 2001. - C. 153-161.

[6] Lazorin S. N., Papkov H. I., Litvinenko V. I. Deactivation of Coke Chemical Plant Wastes - M.: Metallurgy, 1977. - 238 pgs.

[7] Kovalev Ye. T., Borysenko A. L., Blizniukova M. I. Utilization of Coke Chemical Production Wastes and By-Products // Carbon Chemical Journal. - 2004. - Nos. 5-6. - Pgs. 55-62.

[8] New Road Binders Made of Bottom Sludges and Pitch Distillates / I. V. Brown, V. N. Pinchuhov, V. Ya. Strelnikova et al. // Coke \& Chemistry. - 1981. - No. 10. - Pgs. 50-52.

[9] Saranchuk V. I., Zbykovsky E. I., Vlasov G. A. Fundamentals of processing fossil fuels. Part I. - Donetsk: Eastern Publishing House, 2003. - 292 pgs.

[10] Eremin I. V., Bronovets T. M. Coal grades and their rational use. Directory. - M.: Nedra, 1994.- 254 pgs.

[11] Eremin I. V., Lebedev V. V., Tsikarev D. A. Petrography and physical properties of coals. - M.: Nedra, 1980.- 263pgs.

[12] Kienle H., Bader E. Active coals and their industrial applications. - L-d, Chemistry, 1984.- 216 pgs.

[13] Kuznetsov BN Catalysis of chemical transformations of coal and biomass. - Novosibirsk: Science, Sib. branch, 1990. - 302 pgs.

[14] Handbook of an oil refiner / Edited by G. A. Latovkin, E. D. Radchenko, M. G. Rudin. - L-d, Chemistry, 1986.- 648 pgs.

[15] Elishevich A. T. Coal briquetting with binders. - M.: Nedra, 1972-160s. 